\title{
New Possibilities FOR PROJECT MANAGEMENT THEORY: A CRITICAL ENGAGEMENT
}

\author{
SVETLANA CICMIL, Bristol Business School, \\ University of the West of England \\ Bristol, U.K. \\ DAMIAN HODGSON, Manchester Business School, \\ University of Manchester, U.K.
}

\begin{abstract}
This paper provides avenues for a broader engagement with the conceptual considerations of projects and project management with the aim of creating new possibilities for thinking about, researching, and developing our understanding of the field as practiced. Attention is drawn to the legacy of conventional but deeply rooted mainstream approaches to studying projects and project management, and implications of the specific underpinning intellectual tradition for recommendations proposed to organisational members as best practice project management. The identified concerns and limitations are discussed in the context of project management evolution where taken-for-granted advantages of project management as a disciplined effective methodology and its popularity are reexamined. The paper sheds light on a variety of voices from both scholarly and practitioner communities that have attempted to respond to this paradox and move the field forward. Taking issue with conventional labels of project success or failure, and drawing attention to alternative theoretical and methodological propositions, the argument turns toward critical management studies, outlining the implications of this intellectual tradition for studies of projects, project management, project performance, and individual skills and competencies to cope with social arrangements labelled "projects."
\end{abstract}

Keywords: project management theory; project management methodology; research and development

(1)2006 by the Project Management Institute Vol. 37, No. 3, 111-122, ISSN 8756-9728/03

\section{Introduction}

$\|$ oncepts developed by the academic community... must be recovered from operational and textbook definitions and reconnected to ways of seeing and thinking about the world. In the dialectics of the situation and the talk of individuals with different perspectives, the emergence of new ways of talking becomes possible" (Alvesson \& Deetz, 2000, p. 146).

Several prominent authors (Koskela \& Howell, 2002; Maylor, 2001; Morris, 2004; Morris, Patel, \& Wearne, 2000; Winch, 1996) have raised the need to introduce alternative theoretical approaches to the study of projects, and to identify the implications that they may have for how we organise and manage projects. The purpose of this paper is to address this need, by identifying space outside of the tightly-defined and densely populated conceptual landscape of mainstream project management where other perspectives, other concerns, and other agenda may be articulated and explored ${ }^{1}$. Extant project management literature, we would argue, tends to rely upon the language of design, regularity and control to propose models and prescriptions as a route to increasing the ability of humans to control complex worlds (Stacey, 2001; Wood, 2002), to the exclusion of other approaches or ways of reasoning. As a whole, research into projects and project management remains heavily reliant on a functionalist, instrumental view of projects and organisations, where the function of project management is taken to be the accomplishment of some finite piece of work in a specified period of time, within a certain budget, and to agreed specifications. Most textbooks and professional associations for project management promote this normative view of the field as practiced, which can be summarised as the application of knowledge, skills, tools, and techniques to project activities to meet project requirements. Governed by the tradition of "natural sciences" (e.g., systems theory), the project management body of knowledge emphasises the role of project actors and managers as "implementers" narrowing their role to the issues of control (time and cost) and content (planned scope of work), marginalising their wider potential role as competent social and political actors in complex project-labelled arrangements. Dissemination of "best practice" carries a message about the possibility of the progressive rationalisation of action and a belief in the progressive and cumulative character of knowledge. This typically assumes rationality, universality, objectivity, and value-free decision-making, and the possibility of generating law-like predictions in knowledge. 
The limitations and challenges to this view of projects are, however, widely recognised across the field, and increasingly within the project management community itself. Project management has attracted significant attention from an increasing number of researchers and practitioners across management disciplines, coincident with the increased "adoption" of project-based work across industrial sectors (Cicmil, 2001; Hodgson, 2002; Kreiner, 1995; Packendorff, 1995). At the same time, the foundations and practical application of this managerial technology, embodying the scientific achievements of operational research in work scheduling and control under specific constraints of time, cost, and a unique outcome, have been seriously questioned by both the academic and practitioner communities. Several important writers in this field maintain that little radical examination of the intellectual foundation of project management has been done within this stream of research, arguably since the $1960 \mathrm{~s}$ (Koskela \& Howell, 2002; Morris, 1997). In the same vein, writers such as Frame (1994, 1995, 1999), Morris (1997), and Maylor (1999, 2001), among others, have called for a reexamination of the dominant doctrines in project management for their failure to deliver on their promises. Nonetheless, there are limitations to this self-critique; the tendency in the field is still to start from the assumption that the basic framework of project management is compelling and essentially sound. Efforts have therefore been directed instead towards searching for improvements in traditional models and skills (see, for example, Maylor, 2003; Meredith \& Mantel, 2003; Young 1999, 2003) towards a model that better represents the "true" nature of projects, or for a method of project management based on "critical success factors" (Belassi \& Tukel, 1996; Belout, 1998; Boddy \& Paton, 2004; Kharbanda \& Pinto, 1996; Stallworthy \& Kharbanda, 1985), with the assumption that such an ideal model can objectively exist in the world of practice. There is little evidence yet that the resulting torrent of competing streams of thought, methods of inquiry, and best practice claims and propositions has creatively contributed either to constructive debate in the field or to the resolution of difficulties encountered in practice.

To address this situation, we intend through this paper to create an opportunity to stand back and problematise that which seems known and accepted about projects. Taking this concern as its point of departure, our aim is to open up new trajectories within the research agenda in the field of studies relevant to projects, project performance and project management (Hodgson \& Cicmil, 2006a). The starting objective is to critically evaluate the intellectual foundations of project management as a field of study and a practicing discipline, to expose and understand the key obstacles to innovative research and the creation of knowledge communicable and relevant to practitioners, and to broaden the research agenda by encouraging a more critical approach in this area of organisational life. In particular, the paper will explore the potential of critical research in enhancing the intellectual basis of the project management subject area.
As a tentative starting point, therefore, we would pose some fundamental questions that might guide our reflection on how projects are conceived and how they could be conceived:

- Is there a universal explanation of what projects are and how projects evolve?

- What is the meaning behind the concepts in use, that is, the terms such as "project", "project management," and "project success"?

- What are the implications of the "mainstream" definitions of "project'"and "project management" for the nature of knowledge and the intellectual foundations of studies of project-based organising, work, and management?

- What are the consequences of project organising as currently prescribed, both for project managers and project workers?

-What alternative perspectives upon projects exist beyond the mainstream?

- Whose interests are being served by the reproduction of the status quo in the field?

To understand why we have highlighted this sort of concern (and, equally importantly, why we feel such concerns are not routinely considered in the vast "mainstream" literature on projects), we will need to locate our discussion within a reexamination of the evolution of project management. In doing so, we aim to underline why projects merit such serious attention, and to account for their rising popularity and importance in contemporary organisations.

\section{Project Management in Perspective}

Project management emerged as a social practice in the post-World War II development of technology and infrastructure. Although for many writers, project management has a much longer ancestry, traceable back to prehistoric times, we would strongly oppose this ahistorical perspective (Hodgson \& Cicmil, 2006b), which affords a spurious pedigree to techniques, models, and procedures that have existed in something close to their current incarnation for certainly less than a century. The emergence of project management is described in some detail by Morris (1997) and Engwall (1995), highlighting its development in practice through a number of major projects that can be traced back to the Manhattan project in the 1940s. Although the U.S. oil and chemicals industry played a major role in this period, the majority of the groundwork was done in U.S. defence and aeronautics in the 1950s, including widespread use in the Apollo space programs (Harrison, 1981). As is evident from contemporary writings (Gaddis, 1959), the Cold War acted as a significant driver on project management development in the U.S. throughout this period. The intellectual activity in developing the field until the 1960 s was based almost exclusively on quantitative techniques within operational research (OR). During the 1960s and 1970s, the predominantly technicist approach was criticised and the theoretical foundations of the field expanded (Packendorff, 1995; Winch, 1996) to encompass traces of organisational 
research and theories largely concerned with project organisation structures (i.e., the matrix form), project leadership, the role of human resource management in facilitating project work and advice on project team building. In the 1980 s and 1990 s, there was a revival of the OR-based project management research driven by the developments of computerbased technology, which resulted in the creation and promotion of sophisticated expert systems for project planning, control and risk analysis, and an increased use of terminology such as project information systems, project communication networks, etc. This was in no small measure due to the awakening of public sector clients, including government agencies, in their search for robust management models and procedures to minimise disasters of budget and time overruns and questionable quality associated with the project work and outcomes delivered by contractors. A variety of project control methodologies (for example, the PRINCE family) and risk management schemes have been developed against such a background. Despite the increased sophistication of these models for project planning and monitoring, researchers found that only the most basic ones are actually used by practitioners and that they are not always used as intended (Packendorff, 1995).

The 1990s saw an expansion of the project management field of study from its engineering heartlands into what became widely accepted as a "multidisciplinary subject," significantly engaging business and management researchers and educators (Winch, 1996). This coincided with the promotion and acceptance of project-based work, organising, and management across industries and sectors, as a powerful and universal organisational response to the challenges of managing in a complex world. As Clarke (1999, p. 139) stated: "In a world where change is becoming increasingly important, tools such as project management, if used properly, can provide a useful way for organisations to manage that change effectively." It is usually based on the introduction of a set of procedures, or on a new model of administration with the strategic aim to enhance competitiveness through a more effective intra-organisational integration and optimal utilisation of scarce resources (Cleland, 1997).

The contemporary surge in interest in project management is typically explained by reference to the increasing recognition of "the project" as a versatile, flexible, and predictable form of work organisation. Its image as a universal solution to organisational problems has been established on the promotion of specific techniques for planning, monitoring, and control, tried and tested in the operations of traditionally project-oriented industries such as defence, aerospace, and construction (see, for example, Frame, 1999; Maylor, 2001; Young, 1999). Projects and project teams have been hailed in both practitioner and academic discourses as unique economic and social processes on which the emerging "knowledge economy" heavily relies (Briner \& Hastings, 1994; Clarke 1999; Cleland, 1997; Cleland \& Ireland, 2002; Frame, 1994, 1995; Meredith \& Mantel, 2003; Young, 2003). They are promoted as universally applicable templates for integrating, by design, diverse functions of an organization that enable concentration of flexible, autonomous, and knowledgeable individuals in temporary project teams, for the focused accomplishment of goals efficiently, timely, and effectively, for customer satisfaction and company benefits. Despite the various streams of praise and criticism in the last 50 years, then, project management and projects have now been accepted by many both within and outside the field as natural, self-evident, and indispensable.

The promotion of projects and project management continues to expand as knowledge-intensive firms increasingly based on project models have been acclaimed by many as the organisation of the future (Frame, 1999; Weick, 1995). Thus, Frame, for example, claims confidently that the underlying reason for the projects becoming the central focus of management activity in many organisations can be stated "in a single word: competition" (1999, p. 4, italics original). The literature since the 90 s has drawn attention to the centrality of project-based organizing and project working in the processes of information sharing and knowledge management in organizations (Davenport \& Prusak, 1998; De Fillipi, 2001; Hansen, Nohria, \& Tierney, 1999; Silver, 2000Wiig, 1997). Cleland (1997) pointed out that, as project teams evaluate new technologies and resources, they gain insights into the need for making changes. Projects supposedly provide, according to Cleland, a central point where new knowledge, skills, and attitudes can be developed. The received wisdom of this kind has resulted in a widespread adoption of "the project" in contemporary organizations as the focal unit of their operations. Not only are projects considered suitable ways to control endeavours in a turbulent environment (Ekstedt, Lundin, Soderholm, \& Wirdenius, 1999), but also more importantly, they are regarded as the appropriate way to stimulate a learning environment and enhance creativity so as to deliver complex products (Hobday, 2000). Despite the inherent contradiction between these two arguments for project-based organising (Tjaeder \& Thomas, 2000), it is precisely upon this ambitious promise to deliver both "controllability and adventure" (Sahlin-Anderson \& Söderholm, 2002) that the attraction of organisational "projectification" is founded.

In certain academic circles, the expanding influence of "project-based work" has been referred to as the projectification of society (Jessen, 2002; Lundin \& Söderholm, 1998; Midler, 1995; Sydow \& Staber, 2002). In essence, this notion attempts to capture the growing colonisation of all quarters of life by project-related principles, rules, techniques, and procedures, aspiring to form a new "iron cage" of project rationality (Hodgson \& Cicmil, 2003). As more and more organisational members are consequently being redefined as project workers and project managers across industrial sectors, both scholarly and practitioner communities are reflecting upon the implications of this shift for employees and organisations (Hodgson, 2002; Packendorff, 1995), particularly in terms of the impact on workplace identity, reshaped intersubjective interaction, and increased control over the individual through ideologies of efficiency and performativity (Fournier \& Grey, 2000). These mechanisms are 
actualised in a number of project-related contemporary tendencies including the use of information technology (IT) in business process restructuring, the promotion of self-managing teams, the ideology of the "knowledge society" and the "knowledge worker," and the emergence of the projectbased organisation. The resulting drive towards the professionalisation of the project management discipline has been accompanied by the struggle and tensions involved in conceptualising, promoting, and agreeing on the universally acceptable document that should outline the formal body of project management knowledge. This struggle reflects and encapsulates the competition between the nationallyembedded professional associations of project management, with distinct bodies of knowledge proposed by the (U.S.-based) Project Management Institute, but also the (U.K.-based) Association for Project Management, the Japanese Engineering Advancement Association (ENAA), the International Project Management Association (European in origin), in addition to the British Standards Institute (BSI) Guide to Project Management (BS6079) and the numerous corporate models such as Ericsson's "PROPs" model (Linde \& Linderoth, 2006). Despite the ongoing debates, however, project management is the focus of unprecedented interest in the first decade of the new millennium. This interest in many senses flies in the face of the question marks that remain over the effectiveness of project management, the theoretical underpinnings of project management theory, and the transferability of project management into novel industrial sectors and organisations.

\section{Project Management in Question}

In the closing decade of the 20th century, project management was challenged more seriously than in any previous period. Despite the levels of research founded on the presumptions of instrumental rationality in decision-making and control, it is increasingly apparent that accepting and applying such orthodoxy does not eliminate project failures, nor does it guarantee project success (Williams, 2004). Although the project management body of thought has been substantially modified over the last decade, the core concerns continue to shape academic enquiry and practitioners' discourses about projects and project management. Contemporary studies of project performance continue to indicate the disparity between the maturing body of project management know-how and the effectiveness of its application (Atkinson, 1999; Belassi \& Tukel, 1996; Baker, Murphy, \& Fisher, 1983; Morris et al., 2000; Williams, 1995), as an increasing visibility is being given to the claims about project and project management failures, and about dissatisfaction with project performance and outcomes by affected stakeholders. Simultaneously, a growing body of literature, as well as a growing body of empirical evidence and the voices of numerous practitioners, supports the view that the very reason for using projects and project management as a methodology for organisational innovation and change is at the heart of project failures (Clarke, 1999; Maylor, 2001; Thomas, 2000).
A glance at the content of recent public reports and those recorded in previous studies (e.g., Atkinson, 1999; Ewusi-Mensah \& Przasnyski, 1997; Flyvbjerg, Bruzelius, \& Rothengatter, 2003; Flyvbjerg, Holm, \& Buhl, 2002; Morris \& Hugh, 1987; Standish Group, 1995; Williams, 1999; Winch, 1996) provides an insight into frequent cost overruns, delays, and underperformance in terms of quality and user satisfaction, which seem to have become the rule and the reality of contemporary projects. In 1995, for instance, it was estimated by the Standish Group that American companies and government agencies spent US $\$ 81$-billion on cancelled IT projects (Ewusi-Mensah \& Przasnyski, 1997). In addition, the same source reports that, in total, $31 \%$ of IS/IT projects were deemed complete failures; $53 \%$ were late, over budget, and did not meet expectations; only $9 \%$ of IT projects were delivered on time or within budget; and a mere $16 \%$ were considered successful. The average time overrun has been identified as being $222 \%$ of the original estimate. The question often raised in public about this issue is, generally, how the IT/IS project risk (both financial and service risk) is shared and transferred among the public sector and private sector participants.

In January 2000, The Financial Times reported, for example, on the "fiascos" of the major government IT projects in the U.K. "stemming from basic project errors" that "highlighted the need for greater professionalism in project management... The government's track record in project management has been, to say the least, poor" (Whitehall, 2000). Here, the blame was attributed to a lack of specialist project management knowledge among some civil servants and ministers, and to different approval systems, which have, according to some observers, resulted in unrealistic project deadlines. A growing body of evidence shows that similar observations and conclusions have been made in relation to IT/IS in other sectors and types of organisations. It is not only the poor performance of IS/IT projects that has come under public scrutiny. Bowen, Clark, Holiday, and Wheelwright (1994) reported that nearly $30 \%$ of product development projects never live up to business objectives. According to Winch (1996), U.K. government-procured construction projects ranging from hospitals to roads, suffer from, on average, $14 \%$ cost overrun and $11 \%$ time overrun. More recently, the $£ 214 \mathrm{~m}$ refit project of the Royal Opera House in Covent Garden resulted in a cancelled opening performance, and the remaining shows being run at huge technical risks associated with the operation of newly installed but not properly tested and mastered backstage equipment (Royal Opera House, 1999). The Jubilee line extension project for the London Underground, for example, has been characterised as having been "... a long saga of overshot deadlines and overspent budgets" (Winder, 1999, p. 8). In the United States, the belated opening of Denver International Airport after four embarrassing postponements, various scandals, and a final cost of US $\$ 5$ billion against the budgeted US $\$ 1.5$ billion, has been held up as yet another example of project failure (Dempsey, Goetz, \& Szyliowicz, 1997). The much-derided construction of the 
Scottish Parliament Building was described by the Fraser report in September 2004 as being two-and-a-half years behind schedule with costs running approximately 10 times more than the original estimate of $\$ 40 \mathrm{~m}$. The conclusion drawn about the destiny of such projects as a rule, inherent in their very nature, is simple: "These projects never go according to plan" (Royal Opera House, 1999).

In light of this, it is unsurprising that governments are taking a greater interest than ever before in project management, in an attempt to address this apparently perennial failing of project management techniques. As previously noted, governments, and, in particular, the U.S. government, has been closely involved in the development of project management models and techniques for over half a century. The U.K. Office of Government Commerce (OGC) within the British Treasury, for example, has developed and promoted the well-established PRINCE and PRINCE2 models, and is currently taking the lead in setting up Centres of Excellence for Project and Programme Management throughout the U.K. Similar initiatives by government agencies in North America and elsewhere indicate the seriousness with which project management models and practices are now considered in the public sector. Meanwhile, the ongoing professionalisation of the field of project management, and the increased influence of professional associations through accreditation of training and credentialism, draws significant support and gains moral legitimacy from this perceived role in protecting public interests and ensuring the effective use of public funds.

\section{Diagnoses and Prescriptions}

Although the existence of a crisis of some kind in the field of project management is recognised in many (although not all) quarters, the diagnoses in the field are unsurprisingly varied. For many established project management writers, the failings of project management are to be expected in a maturing field. As techniques are further honed, and models are perfected through longitudinal and cross-sectoral research, it is assumed that the field will one day settle upon a reliable and basically effective model and array of techniques. Others see the problem as far more deeply rooted in the fundamental principles upon which the field of project management has been established. In this section, we will look at each of these accounts in turn, considering first the attempts by the mainstream of project management to confront the very real failings in the discipline, before turning to a more critical diagnosis of the current state of project management.

It is not our claim, then, that project management as a disciplinary area is unaware of, or unconcerned by, the limitations and continued failings of project management models and methods. There is a long-standing debate on the international scene about the formulation of the formal, professional project management body of knowledge, in which important questions are posed by the proponents of project management about the boundaries of the project management subject area, its purpose, practical application, and relationship with other aspects of organisational and managerial reality (Frame, 1999; Meredith \& Mantel, 1995, 2003; Morris et al., 2000; Walta; 1995; Wideman, 1995; among others). Despite the significant presence of projectbased working and organising across industrial sectors and the problematic qualifications of project outcomes as success or failure, a number of authors note that the development of project management knowledge remains unstable and fragmented. As a consequence, the dream of establishing project management as an exemplary field of management science is becoming increasingly remote. Questions have been raised about the underlying belief system that exhibits a strong bias towards functionalist/unitarist tradition, reductionism, operational research, and "how-to-do" prescriptive forms of intellectual output (Buchanan \& Badham, 1999; Kreiner, 1995; Packendorff, 1995). It was mainly in the 1990s that critical analysis of social and political power associated with projects as organisational and social arrangements, and project management as a practice and as a social grouping emerged in an explicit form (Buchanan and Badham, 1999; Buchanan \& Boddy, 1992; Kreiner, 1995; Lundin \& Hartman, 2000; Lundin \& Midler, 1998; Packendorff, 1995).

Nonetheless, the response to this crisis has so far been a yet-greater emphasis on technicist solutions, quantitative methodologies, positivist methodologies and a stronger reliance on instrumental rationality. In one attempt to move the field forward, Atkinson (1999) asserted that it has become an impossible, and, most likely, non-"value-adding" endeavour to define project management in terms of the traditional "iron triangle" principles, emphasising the achievement of time, cost, and quality objectives as the major justification for the role of project management. According to Atkinson, the attention should be refocused from these efficiency measurements, which are being questioned as appropriate measures of project success (see also Baldry, 1998; Belassi \& Tukel, 1996; Chapman, 1998; Maylor, 2001).

The issue of ambiguity associated with qualifying a project as success or failure has recently attracted scholarly attention (e.g., Boddy \& Paton, 2004; Buchanan \& Badham, 1999; Clarke, 1999). The debate focuses on a more strategic level of decision-making, in which project failure appears to be "strategic" rather than linked to technical problems, and is seen as a result of political processes of resistance in organisations. Accounts pointing to the evidence of mounting dissatisfaction and lack of support imply a range of social and behavioural factors behind project failures. Other authors suggest the need for a wider picture of what goes on in social construction of projects and project management by focusing on who is included in, and who is excluded from, the decision-making process, analysing what determines the position, agendas and power of different participants with respect to issues, and how these different agendas are combined and resolved in the process by which the decisions are arrived at (Flyvbjerg et al., 2003). In the context of IT/IS project failures, Taggert and Silbey (1986) cynically propose a political-development cycle of projects: wild 
enthusiasm, disillusionment, total confusion, search for the guilty, punishment of the innocent, and promotion of nonparticipants, in contrast to the conventional rational project life cycle (PLC) model, which neatly unfolds as a succession of stages: conception and feasibility study, requirement analysis and specification, design and development, implementation/execution, and project termination.

On the basis of his research into IT projects, Fincham (2002) argued that project failure can be interpreted in a wide range of ways, joining the writers who focus on political discourses, language and interpretation related to organisational reporting on project performance. Arguing that all projects exhibit, to a smaller or larger extent, a dimension of organisational innovation and change, Fincham suggested that the attributions of "success" and "failure" can also be explored as narratives that are involved in many forms of change and innovation in organisations. "Through a kind of social labelling events are formulated into evolving 'stories' that evoke either status or stigma and play a powerful role in ordering behaviour" (Fincham, 2002, p. 1). From that perspective, the management of projects and the change associated with its initiation and outcomes is equated with the "management of meaning" (Huczynski \& Buchanan, 2001), or with symbolic attempts to legitimise project proposals and particular definitions of problems and solutions in the face of competing ideas. Similarly, Fincham (2002) observed that "[t]he gloss of success is often critical for projects that may involve large expenditures and much uncer-

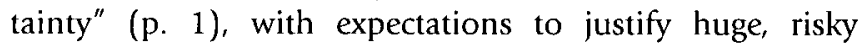
investments. Such a frame of reference emphasises the need to understand organisational processes of power, politics, structure, and their interplay with the nature of interaction among individuals and interest groups involved in development and implementation of a project.

Table 1 summarises different approaches to understanding project failure by distinguishing three perspectives and linking them to a wider domain of the project management process. This table has been adapted from Fincham (2002), who termed the three approaches as rationalist, process, and narrative. The first two essentially reflect the idea of Sauer (1999) who differentiates between a factorbased approach and a process approach to project failure, which is largely present in the extant project management body of thought. The third (narrative-Fincham, 2002) is related to a much less frequent approach to project performance research, but is the one that is of most interest to this paper.

The exploration of the performance characteristics of public initiatives, such as large-scale engineering projects, has expanded these performance measures to include a discussion of the role of institutions, risks, and governance in project success (Flyvbjerg et al., 2003; Miller \& Lessard, 2000). For others, it is the paradoxical feedback that hinders the effective adoption of project-based working and organising as a structural innovation in complex business environments. Whereas project management has been mobilised as a blueprint for structuring and coordinating organisational change, according to Clarke (1999): "People often do not see project management as something to help them but rather something which is mandatory, serving little useful purpose" (Clarke, 1999, p. 144). Clarke identified the following as problematic in the application of project management as a vehicle of change; the rigid "standardisation" of project management as the mode of change management that often causes cultural clashes; project management, or "managing by projects" or becoming a "project-based" organisation is often regarded as another control mechanism, a "corporate reporting" tool; the inadequate formal completion of change projects; project overload syndrome; individual resistance to imposed procedures and practice, and a lack of confidence and motivation. It becomes obvious that, frequently, the very principles of effective, structured project management methodology are simultaneously its major causes of failure.

Another influential attempt to address the malaise comes from what is known as the "Scandinavian School" of project studies (Ekstedt et al., 1999; Lundin \& Hartmann, 2000; Lundin \& Midler, 1998; Lundin \& Söderholm, 1995;

\begin{tabular}{|l|l|l|l|}
\hline Perspective & $\begin{array}{c}\text { Form of Organisational } \\
\text { Behavior and Action }\end{array}$ & \multicolumn{1}{|c|}{$\begin{array}{c}\text { Methodological } \\
\text { Focus }\end{array}$} & $\begin{array}{c}\text { Success and Failure } \\
\text { Seen As }\end{array}$ \\
\hline Rational/normative & $\begin{array}{l}\text { Organisational goals; } \\
\text { managerial and } \\
\text { organizational structures } \\
\text { surrounding the project }\end{array}$ & Simple cause and effect & $\begin{array}{l}\text { Objective and polarised } \\
\text { states }\end{array}$ \\
\hline Processual & $\begin{array}{l}\text { Organisational and socio- } \\
\text { political processes; } \\
\text { projects as form of a } \\
\text { decision outcome }\end{array}$ & Socio-technical interaction & $\begin{array}{l}\text { Outcomes of organizational } \\
\text { processes }\end{array}$ \\
\hline Narrative & $\begin{array}{l}\text { Organisational and socio- } \\
\text { political processes; symbolic } \\
\text { action; themes }\end{array}$ & $\begin{array}{l}\text { Interpretation and sense- } \\
\text { making; rhetoric and } \\
\text { persuasion; critical/ } \\
\text { hermeneutics }\end{array}$ & Social constructs; paradigms \\
\hline
\end{tabular}

Table 1: Perspectives on project success and failure (adapted from Fincham, 2002, p. 3) 
Sahlin-Andersson \& Söderholm, 2002; Söderlund, 2004). In the 1990s, Packendorff succinctly summarised the concern shared by a group of Scandinavian scholars, arguing that contemporary propositions for the improvement of project management knowledge and practice were ill-conceived, reflecting fundamental misconceptions within the field. He identified three major deficiencies which are ingrained, maintained, and reproduced across the research field through certain ontological, epistemological, and methodological assumptions: (1) the assumed universality of project management theory, (2) the lack of empirical studies of projects, and (3) the lack of alternative representations of "projects" (summarised in Table 2),

Emerging from this school are a number of vital themes that move beyond traditional understandings of projects and their management: the conceptualisation of projects as temporary organisations (Lundin \& Söderholm, 1995); the recognition of the historically-embedded nature of projects (Engwall, 2003; Kreiner, 1995); and the shift in focus from single to multiple project management (Engwall \& Jerbrant, 2003). Although this introduction of sociological perspectives to the field of projects is clearly welcome-indeed, long overdue-the more conservative current work in this tradition remains strongly wedded to a functionalist viewpoint, focusing upon improving project performance through attention to social (i.e., human) factors. Equally, within this perspective, the inclusion of power and power relations tends to be limited to the introduction of a form of micropolitics, separated from the larger power differentials inherent in modern, capitalist society. Although there is much to be drawn from the Scandinavian School, and much that improves upon the narrow mechanistic instrumentalism of traditional project management, we would argue that the school remains too conservative in its ambitions, and does not take its argument to its logical conclusions. It does, however, open the space of project studies to more explicitly "critical" currents, and some of the strongest critical work on projects to have emerged so far has its roots in the advances made by the Scandinavian School (see, for example, Lindgren \& Packendorff, 2001, 2006).
Our proposal in this paper is to draw on the insights offered by writers and academics within the broad grouping of critical management studies to widen and deepen the theoretical foundations of project management and to provide novel approaches to the entrenched challenges facing project management. We foresee that this would require a fundamental reappraisal of many of the core tenets of project management theory and techniques, a stance that may be uncomfortable for many whose careers and indeed livelihoods are intimately connected to project management as it stands. Nonetheless, we argue that without such a radical reappraisal of the field, project management as a discipline will not surmount the practical and philosophical concerns that it currently faces, and will struggle to exercise a significant influence on the ever-wider application of project organising in the years to come.

\section{Critical Perspectives on Projects}

Critical work on management and organisations has a broad, even eclectic base, and draws upon a wide range of social theories, philosophies, and ethical/moral positions, including Marxism, feminism, environmentalism, labour process theory, post-structuralism, post-colonialism and critical realism. Work in this field draws its inspiration and theoretical frameworks from a wide range of writers, including Weber, Braverman, Derrida, Latour, Bourdieu, Baudrillard, Foucault, Habermas, Bhaskar, among others. In what stands as the most coherent summary of the principles underpinning this diverse field, Fournier and Grey (2000) set out three key tenets that critical work shares. They argue that critical research on management and organisations:

1. Has a "Non-Performative Intent"-Starts out from the position that issues of morality, equality and ethics are at least as important as, and in many senses more important than, the traditional functionalist concerns of effectiveness and efficiency of management.

2. "Aims to Denaturalise Organisations \& Management"-Challenges arguments that the current way in which organisations, economies, and societies are organised is somehow natural, normal

\begin{tabular}{|c|c|c|}
\hline & Common Assumptions & Alternative Assumptions \\
\hline Project management theory & $\begin{array}{l}\text { General theory for all kinds of projects, } \\
\text { generic concept collecting different } \\
\text { theories applicable to projects under } \\
\text { one umbrella }\end{array}$ & $\begin{array}{l}\text { Middle-range theories on different } \\
\text { sorts of projects, classified according } \\
\text { to different selection criteria }\end{array}$ \\
\hline Aim of research on projects & $\begin{array}{l}\text { Prescriptive, normative theory, } \\
\text { grounded in ideal models of project } \\
\text { planning and control. Research } \\
\text { undertaken as survey studies of large } \\
\text { samples of projects }\end{array}$ & $\begin{array}{l}\text { Descriptive theory, grounded in } \\
\text { empirical narrative studies on human } \\
\text { interaction in projects. Research } \\
\text { undertaken as comparative case } \\
\text { studies }\end{array}$ \\
\hline Research metaphor for the project & $\begin{array}{l}\text { A tool, a means for achieving higher- } \\
\text { level ends }\end{array}$ & $\begin{array}{l}\text { A temporary organisation, an } \\
\text { aggregate of individuals temporarily } \\
\text { enacting a common cause }\end{array}$ \\
\hline
\end{tabular}

Table 2: Common and alternative assumptions on project management (adapted from Packendorff, 1995, p. 326) 
or inevitable, arguing instead that the status quo is a consequence of the prioritisation of the agenda of certain social groups, and benefits these groups at the expense of others.

3. "Aims to Prevent Oppression/Exploitation"-The overarching mission underpinning critical work is to highlight and oppose oppression and exploitation in organisations and societies. Typically, this refers to the exploitation of employees, of women, of ethnic minorities, or of the environment.

Much of this work (for example, Alvesson \& Willmott, 1996; Reed, 1992; Thompson \& McHugh, 2002) has since the mid-1990s been collectively referred to as critical management studies(CMS), which has also lent its name to a major.international conference (CMS5, to be held in 2007), as well as to a major interest group at the Academy of Management. Such work takes issue with positivist epistemology in the field of management, insofar as it perpetuates the belief that managers face an objective reality that they can control by applying suitable methods for a rational assessment of the problematic situation in order to come up with the correct solution. The consequence of this is a proliferation of methods, tools, analytical techniques, and applied instruments with which management itself becomes identified. Management skills and knowledge are reduced to value-neutral competence, ignoring the political aspect of organisations, and ethical and moral issues, reinforcing the belief that management can be conceptualised in a technical way by agreeing on terminology and meaning. Managers are seen as rational technicians, dealing with technical issues that are resolvable through the application of superior knowledge of the planning and control techniques. Alvesson and Deetz have commented on the problems with narrow, conventional approaches to studying the phenomenon of management and the need to adopt a much more critical stance and varying theoretical lenses:

There is considerable agreement that conventional, universal statements of what management is about and what managers do-planning, organizing, coordinating and controlling-do not tell us very much about organisational reality, which is often messy, ambiguous, fragmented and political in character (Alvesson \& Deetz, 2000, p. 60).

It is argued that conventional approaches to organisational and management research have exposed managers and other employees involved in problem-solving and decision-making to an overwhelming amount and range of techniques (empowerment, teamwork, flexibility), which can be interpreted as "covert tools of manipulation and exploitation" (Huczynski \& Buchanan, 2001, p. xxi).

More work has emerged that applies this critical position to project management, its nostrums and methods (see, for example, Bredillet, 2002, 2004; Buckle \& Thomas, 2003; Cicmil, 2003; Cicmil \& Hodgson, 2005; Gill, 2002; Hodgson, 2002; Hodgson \& Cicmil, 2003; Metcalfe, 1997; Packendorff, 1995). The most important requirement for the development of critical project management studies is the inclusion of critical social theory into the research process. Central to it is the need to explore how the relationships between individuals and collectivities are being constituted and reproduced in the context of project management, and how asymmetrical power relations create and sustain the social reality of projects. In this context, we argue that the main issue for the project management research community should not be what form of critical analysis is best suited for enhancing the intellectual basis of critical management studies. Drawing on critical theory and particularly the contribution of Jurgen Habermas, Alvesson, and Willmott (1996) suggest that intellectual efforts should be focused on encouraging inspiration from a variety of theories and ideas, as a counterforce to technicist and instrumental forms of rationality in project environments. From a Habermasian perspective, it might be argued that the objective, abstract and universal body of knowledge claimed in a number of authoritative sources as proprietary to project management fails to live up to the challenges of the embodied and power-laden realities of its operation. "Project management" as created by this school of thought, exhibits the characteristics of what Alvesson and Willmott (1996) called management as colonising power and management as distorted communication. From this perspective, the possibility of critical project management will depend on the extent to which a social theory about the nature of projects provides concerned actors with authentic insights into their position in project environments, leading to their enlightenment, changed attitudes and emancipatory action.

Another major influence on critical work with implications for an understanding of project management is the wide and varied oeuvre of Michel Foucault, drawn upon by writers such as David Knights, Stewart Clegg, Barbara Townley, and Stanley Deetz, among others. In particular, a key research theme is a focus on the consequences of those techniques of observation, measurement, and performance control central to project management methodologies for both the management and the self-management of workers within project settings. Work on project management in this tradition (Hodgson, 2002; Lindgren \& Packendorff, 2003; Thomas, 2003) tends to criticise the implied calculability and formality of project management methodology, as it embodies a strong functionalist commitment to ensuring, first and foremost, the effective control of workers. In many ways, as previously noted, this control imperative in project management is traditionally based upon similar principles to those underpinning scientific management: the fragmentation of work and the maximisation of visibility and accountability. However, with isolated exceptions (Metcalfe, 1997), the fundamentals of project work appear to have evaded the practical and moral critique levelled at other Taylorist work forms. At the same time, the ongoing professionalisation of project management can also be interpreted in line with other professionalisation projects, as a mode of control over expert labour (cf. Larson, 1977; Abbott, 1988), implementing and enforcing a form of self-disciplinary con- 
trol over project managers. A key challenge for critical work from this perspective is thus to draw attention to the power relations established and maintained by project management technologies, and the consequences of these power relations. Other critical work on projects includes analysis of the gendered nature of project management models (Buckle \& Thomas, 2003), examinations of the impact of projects working on work-life balance (Lindgren \& Packendorff, 2003), investigations into the role of project management in perpetuating oligarchic elites in modern corporations (Clegg \& Courpasson, 2004), and analyses of project management as a form of bureaucratic control in post-bureaucratic contexts (Hodgson, 2004).

To advance such critical work, we would argue that the scope for critical research into projects and project management, and in particular the emancipatory aspect of such research needs to be expanded. This means a more radical acknowledgment of voices from practitioners in project environments, such as Balck's:

Practitioners, in particular we as project managers, are well advised to rid ourselves of the constricting historical background of a mechanistic world image and rationalism. Without question the best method to help us correct our way of traditional thinking is "on-the-job training" - that is, experiencing the real success and failures in dealing with our everyday business endeavours (Balck, 1994, pp. 2-4).

We would argue that taking this seriously means moving beyond the narrow instrumentalism, which bedevils, yet largely defines, the "iron triangle" approach to project management. Our hope is that this paper may encourage movement towards the creation of a vocabulary and a resource for a critical engagement between practitioners and academics beyond the confines of the existing language, concepts and assumptions of project management.

\section{Making Projects Critical: New Trajectories}

At this point, it is opportune to return to the intentions behind this paper. As stated in the introduction, we aim to open new trajectories within the research agenda in the field of studies relevant to projects, project performance and project management in order to address the persisting and prevailing concerns articulated in literature and practice, which we attempted to briefly illuminate. Our immediate objective, therefore, is to signpost possible research trajectories towards a critical evaluation of the intellectual foundations of project management as a field of study and a practising discipline and to broaden the research agenda by encouraging a more critical approach in this area of organisational life. Explicitly we take up the challenge offered by Flyvbjerg (2001, p. 166) to conduct research that "contributes to society's capacity for value-rational deliberation and action"; in essence, to make social science matter in the context of project work. What, therefore, might it mean for both the scholarly and the practitioner community, to encourage a different way of viewing and thinking about projects and project management as social phenomena through critical studies? How might a consideration of lines of reasoning and practice other than those promoted by narrowly instrumentalist project management thinking respond to the identified crisis in the field?

The first and most important consequence of an engagement with critical work would be an increased sensitivity to the possibility of oppression and exploitation in project settings, an outcome which is especially likely given the pressurised environment of most projects, regardless of sector and scale. A second important aspect of critical approaches to project management is to reexamine the currently dominant imperative of performativity in relation to how this shapes the development of the body of knowledge and best practice in the field (particularly related to "critical factors for project success") and illuminate the importance of considering other indicators of "project success" beyond time, cost, and quality performance, to encompass environment, health and safety, economy, and ethics. And, third, critical project management research would engage directly with not merely project managers but with practitioners at all levels of the project hierarchy, as it is interested in specific local situations and the lived experiences of various project actors, often with the aim of initiating some transformative redefinition (Alvesson \& Deetz, 2000) of actors' own perception of self, their voice, and their influence in shaping their own social roles and place.

Our intention in presenting these views is primarily to start a dialogue, to raise the importance of such issues and concerns within the field of project management, and to draw attention to broader theoretical resources available to conceptualise projects and their management. To this end, we have in the past organised workshops to act as forums for debates around these themes, of which the best papers have been published as a collection (Hodgson \& Cicmil, $2006 \mathrm{~b}$ ). We will continue to run these workshops, in the hope of extending the debate and learning from the views, experiences and insights of as broad a range as possible, and we would welcome interventions, participation, and even counter-critique from all quarters. We hope that, at the least, this paper has succeeded in raising new concerns and has sharpened interest among project management academics and practitioners to engage with these concerns, which are central to the future of a sustainable and ethical project management.

\section{Notes}

${ }^{1}$ In this sense, the paper continues the mission of two workshops organised and held at Bristol Business School in the U.K. in 2003 and 2004, with the explicit aim to "make projects critical." These workshops brought together a diverse community of researchers and practitioners from Europe, North America, and Australasia with a common interest in considering vital issues and values that are both ignored and obscured by "mainstream" project management. Details can be found at http://www.uwe.ac.uk/bbs/research/research/mpc/index.shtml 


\section{References}

Abbott, A. (1988). The system of professions: An essay on the division of expert labour. London: University of Chicago Press.

Alvesson, M., \& Willmott, H. (1996). Making sense of management: A critical introduction. London: SAGE.

Alvesson, M., \& Deetz, S. (2000). Doing critical management research. London: Sage.

Association for Project Management (APM). (1995). Body of knowledge, Version 2, January 1995 APM: London.

Atkinson, R. (1999). Project management: Cost, time and quality, two best guesses and a phenomenon; It's time to accept other success criteria. International Journal of Project Management, 17(6), 337-342.

Baker, B. N., Murphy, D. C., \& Fisher, D. (1983). Factors affecting project success. In D. I. Cleland, \& R. W. King (Eds.), Project management handbook (pp. 669-685). New York: Van Nostrand Reinhold.

Balck, H. (1994). Projects as elements of a new industrial pattern: A division of project management. In D. I. Cleland \& R. Gareis (Eds.), Global project management handbook (pp. 2-1-2-11). New York: McGraw - Hill International Editions.

Baldry, D. (1998). The evaluation of risk management in public sector capital projects. International Journal of Project Management, 16(1), 35-41.

Belassi, W., \& Tukel, O. I. (1996). A new framework for determining success/failure factors in projects. International Journal of Project Management, 14(3), 141-151.

Belout, A. (1998). Effects of HRM on project effectiveness and success: Toward a new conceptual framework. International Journal of Project Management, 16(1), 21-26.

Boddy, D., \& Paton, R. (2004). Responding to competing narratives: Lessons for project managers. International Journal of Project Management, 22(3), 225-233.

Bowen, H. K., Clark, K. B., Holloway, C. A., \& Wheelwright, S. C. (1994). The perpetual enterprise machine. Oxford: Oxford University Press.

Bredillet, C. N. (2002). Beyond the positivist mirror: Towards a project management 'gnosis'. Paper presented at the IRNOP conference in Rotterdam, Netherlands, May 28-31, 2002.

Bredillet, C. (2004). Beyond the positivist mirror: Towards a project management 'gnosis'. Paper presented at the IRNOP conference in Turku, Finland August 25-27, 2004.

Briner, W., \& Hastings, C. (1994). The role of projects in the strategy process. In D. I. Cleland \& R. Gareis (Eds.), Global project management handbook (pp. 15_3-15_24). New York: McGraw-Hill International Editions.

Buchanan, D. \& Badham, R. (1999). Power, politics, and organisational change: Winning the turf game. London: Sage.

Buchanan, D., \& Boddy, D. (1992). The expertise of the change agent. Hemel Hempstead, UK: Prentice Hall.

Buckle, P., \& Thomas, J. (2003). Deconstructing project management: A gender analysis of project management guidelines. International Journal of Project Management, 21(6), 433-441.

Chapman, R. J. (1998). The role of system dynamics in understanding the impact of changes to key project person- nel on design production within construction projects. International Journal of Project Management, 16(4), 235-247.

Cicmil, S. (2001). Reconstructing the project management knowledge system: A multiple-perspective agenda. Paper presented to Critical Management Studies Conference, UMIST, Manchester, UK, 11 th-13th July 2001.

Cicmil, S. (2003). Knowledge, interaction and project work: The perspective of complex responsive processes of relating. Paper presented at the 19th EGOS Colloquium, subtheme "Project Organizations, Embeddedness and Repositories of Knowledge," Copenhagen, Denmark, 3-5 July 2003.

Cicmil, S., \& Hodgson, D. E. (2005). Knowledge, action, and reflection in management education-The case of project management. BBS Teaching and Research Review, Issue 7, September 2005; ISSN 1468-4578. Retrieved October 10, 2005, from http://www.uwe.ac.uk/bbs/trr/Is7-cont.htm

Clarke, A. (1999). A practical use of key success factors to improve the effectiveness of project management. International Journal of Project Management, 17(3), 139-145.

Clegg, S. C., \& Courpasson, D. (2004). Political hybrids: Toquevillean views on project organizations. Journal of Management Studies, 41(4), 525-547.

Cleland, D. I. (1997) Field guide to project management. New York: Van Nostrand Reinhold.

Cleland, D. I., \& Ireland, L. R. (2002). Project management: Strategic design and implementation (4th ed.). New York: McGraw-Hill International.

Davenport, T. H., \& Prusak, L. (1998). Working knowledge. Boston: Harvard Business School Press.

DeFillippi, R. (2001). Project based learning, reflective practices and learning outcomes. Management Learning, 32(1), 5-10.

Dempsey, P. S., Goetz, A. R., \& Szyliowicz, J. S. (1997). Denver International Airport: Lessons learned. New York: McGraw-Hill.

Ekstedt, E., Lundin, R. A., Söderholm, A., \& Wirdenius, H. (1999). Neo-industrial organising London: Routledge.

Engwall, M. (1995). Jakten på det Effektiva Projektet. Stockholm: Nerenius \& Santérus.

Engwall, M. (2003). No project is an island: Linking projects to history and context. Research Policy, 32(5), 879-808.

Engwall, M., \& Jerbrant, A. (2003). The resource allocation syndrome: The prime challenge of multi-project management. International Joumal of Project Management, 21(6), 403-409.

Ewusi-Mensah, K., \& Przasnyski, Z. H. (1997). Critical issues in abandoned IS development projects. Communications of the Association for Computing Machinery, 40(9), 74-80.

Fincham, R. (2002). Narratives of success and failure in systems development. British Joumal of Management, 13(1), $1-14$.

Flyvbjerg, B. (2001). Making social science matter. Cambridge, UK: Cambridge University Press.

Flyvbjerg, B., Bruzelius, N., \& Rothengatter, W. (2003). Megaprojects and risk: An anatomy of ambition. Cambridge, UK: Cambridge University Press. 
Flyvbjerg, B., Holm, M. S., \& Buhl, S. (2002). Underestimating costs in public works projects-Error or lie? Journal of American Planning Association, 68 (Summer), 279-295.

Fournier, V., \& Grey, C. (2000). At the critical moment: Conditions and prospects for critical management studies. Human Relations, 53(1), 7-32.

Frame J. D. (1994). The new project management. San Francisco: Jossey-Bass.

Frame, J. D. (1995). Managing projects in organisations. San Francisco: Jossey-Bass.

Frame, J. D. (1999). Project management competence: Building key skills for individuals, teams and organisations. San Francisco: Jossey-Bass.

Gaddis, P. O. (1959). The project manager. Harvard Business Review, May-June, 89-97.

Gill, R. (2002). Cool, creative and egalitarian? Exploring gender in project-based new media work in Europe. Information, Communication and Society, 5(1), 70-89.

Hansen, M. T., Nohria, N., \& Tierney, T. (1999). What's your strategy for managing knowledge? Harvard Business Review, March-April, 1999.

Harrison, F. L. (1981). Advanced project management. Aldershot, UK: Gower.

Hobday, M. (2000). The project-based organisation: An ideal form for managing complex products and systems? Research Policy, 27, 871-893.

Hodgson, D. E. (2002). Disciplining the professional: The case of project management. Journal of Management Studies, 39(6), 803-821.

Hodgson, D. E. (2004). Project work: The legacy of bureaucratic control in the post-bureaucratic organisation. Organization, 11(1), 81-100.

Hodgson, D. E., \& Cicmil, S. (2003, July). Setting the standards: The construction of 'the project' as an organizational object. Paper presented to the 3rd Critical Management Studies Conference, Lancaster University, Lancaster, UK.

Hodgson, D. E., \& Cicmil, S. (2006a). Making projects critical. London: Palgrave.

Hodgson, D. E., \& Cicmil, S. (2006b). Are projects real?: The $\mathrm{PMBOK}$ and the legitimation of project management knowledge. In D. E. Hodgson \& S. Cicmil (Eds.), Making projects critical. London: Palgrave.

Huczynski, A., \& Buchanan, D. (2001). Organizational behaviour: An introductory text (4th ed.). Harlow, UK: FTPrentice Hall, Pearson Education Ltd.

Jessen, S. A. (2002). Business by projects. Universitetsforlaget AS: Oslo, Norway.

Kharbanda, O., \& Pinto, J. (1996). What made Gertie gallop? Lessons from project failures. New York: Van Nostrand Reinhold.

Koskela, L., \& Howell, G. (2002, July). The underlying theory of project management is obsolete. Proceedings of PMI Research Conference 2002 (pp. 293-301). Newtown Square, PA: Project Management Institute.

Kreiner, K. (1995). In search of relevance: Project management in drifting environments. Scandinavian Journal of
Management, 11(4), 335-346.

Larson, M. (1977). The rise of professionalism: A sociological analysis. Berkeley, CA: University of California Press.

Linde, A., \& Linderoth, H. (2006). An actor-network theory perspective on IT projects. In D. Hodgson \& S. Cicmil (Eds.), Making Projects Critical. Basingstoke, UK: Palgrave.

Lindgren, M., \& Packendorff, J. (2001). What's new in new organizational forms? On the construction of gender in project-based work. Paper for the Gender, Work and Organization conference 'Rethinking gender, work and organisation', Keele University, Keele, UK, June 27-29, 2001.

Lindgren, M., \& Packendorff, J. (2006). Projects and prisons. In D. Hodgson \& S. Cicmil (Eds.), Making Projects Critical. Basingstoke, UK: Palgrave.

Lundin, R. A., \& Söderholm, A. (1995). A theory of the temporary organization. Scandinavian Journal of Management, 11(4), 437-455.

Lundin, R. A., \& Söderholm, A. (1998). Conceptualising a projectified society: Discussion of an ecoinstitutional approach to a theory on temporary organizations. In R. A. Lundin \& C. Midler (Eds.), Projects as arenas for renewal and learning processes (pp. 13-23). Boston: Kluwer Academic Publishers.

Marshall, N. (2001). Knowledge, identity, and difference in project organisation. Paper presented at the 17th EGOS Colloquium 'The Odyssey of Organising', Lyon, France, 5-7 July 2001.

Maylor, H. (1999). Project management (2nd ed.). London, UK: Pitman Publishing.

Maylor, H. (2001). Beyond the Gantt chart-Project management moving on. European Management Journal, 19(1), 92-100.

Maylor, H. (2003). Project Management (3rd ed.). London, UK: Pitman Publishing.

Meredith, J. R., \& Mantel, S. L. (1995). Project management-A managerial approach (3rd ed.). New York: John Wiley \& Sons.

Meredith, J. R., \& Mantel, S. L. (2003). Project management-A managerial approach (5th ed.). New York: John Wiley \& Sons.

Metcalfe, B. (1997). Project management system design: A social and organisational analysis. International Journal of Production Economics, 52(3), 305-316.

Midler, C. (1995). 'Projectification' of the firm: The Renault case. Scandinavian Journal of Management, 11(4), 363-373.

Miller, R., \& Lessard, D. R. (2000). The strategic management of large engineering projects. Boston:Institute of Technology Press.

Morris, P. W. G. (1997). The management of projects (2nd ed.). London: Thomas Telford.

Morris, P. W. G. (2002, May). Science, objective knowledge and the theory of project management. Proceedings of the Institute of Civil Engineering, 150, 82-90.

Morris P. (2004). Current trends in project and programme management. In Association for Project Management Yearbook. High Wycombe, UK: Association for Project Management (APM). 
Morris, P. W. G., \& Hough, G. H. (1987). The anatomy of major projects. London: Major Projects Association.

Morris, P. W. G., Patel, M. B., \& Wearne, S. H. (2000). Research into revising the APM project management body of knowledge. International Joumal of Project Management, 18(3), 155-164.

Packendorff, J. (1995). Inquiring into the temporary organisation: New directions for project management research. Scandinavian Joumal of Management, 11(4), 319-333.

Reed, M. I. (1992). The sociology of organisations: Themes, perspectives, and prospects. Hemel Hempstead, UK: Harvester Wheatsheaf.

Royal Opera House cancels performance. (1999, November 24). Financial Times, p. 5.

Sahlin-Andersson, K., \& Söderholm, A. (Eds.). (2002) Beyond project management: New perspectives on the temporary-permanent dilemma. Copenhagen: Liber.

Sauer, C. (1999). Deciding the future for IS failures: Not the choice you might think. In W. L Currie \& B. Galliers (Eds.), Rethinking management information systems (pp. 279-309). Oxford, UK: Oxford University Press.

Silver, C. A. (2000). Where technology and knowledge meet. Joumal of Business Strategy, 21(Nov/Dec.), 28-33.

Söderlund, J. (2004). Building theories of project management: Past research, questions for the future. International Joumal of Project Management, 22(3), 183-191.

Stacey, R. (2001). Complex responsive processes in organisations: Learning and knowledge creation. London: Routledge.

Stallworthy, E. A., \& Kharbanda, O. P. (1985). International construction and the role of project management. Aldershot, UK: Gower.

Standish Group. (1995). Chaos paper. Retrieved March 16th, 2005, from http://www.standishgroup.com/

Sydow, J., \& Staber, U. (2002). The institutional embeddedness of project networks: The case of content production in German television. Regional Studies, 36(3), 215-227.

Taggert, W. M., \& Silbey, V. (1986). Informational systems: People and computers in organizations. Boston: Allyn \& Bacon.

Thomas, J. (2000). Making sense of project management. In R. A. Lundin \& F. Hartman (Eds.), Projects as business constituents and guiding motives. Boston: Kluwer Academic Press.

Thomas, ]. (2003, April). Problematizing project management. Paper presented to Making Projects Critical Workshop, Bristol
Business School, UWE, Bristol, UK.

Thompson, P., \& McHugh, D. (2002). Work organisations. London: Palgrave.

Tjaeder, J., \& Thomas, J. (2000, January). On learning and control-Competing paradigms or co-existing requirements for managing projects in ambiguous situations? Unpublished paper presented to International Research Network on Organizing by Projects (IRNOP) fourth bi-annual conference held in Australia.

Walta, H. (1995). Dutch project management body of knowledge policy. International Joumal of Project Management, 13(2), 101-108.

Weick, K. (1995). Sensemaking in organisations. Thousand Oaks, CA: Sage.

Whitehall counts the costs of IT projects. (2000, January 14) Financial Times, p. 13.

Wideman, R. M. (1995). Criteria for a project management body of knowledge. International Joumal of Project Management, 13(2), 71-75.

Wiig, K. M. (1997). Knowledge management: An introduction and perspective. Joumal of Knowledge Management, 1(1), 6-14.

Williams, T. (1995). A classified bibliography of research relating to project risk management. European Joumal of Operational Research, 85(1), 180-188.

Williams, T. M. (1999). The need for new paradigm for complex projects. International Journal of Project Management, 17(5), 269-273.

Williams, T. (2004, July). Assessing and building on the underlying theory of project management in the light of badly over-run projects. Paper presented at the PMI Research Conference, London.

Winch, G. (1996, September). Thirty years of project management-What have we learned? British Academy of Management Conference Proceedings (pp. 8.127-8.145). Birmingham, UK: Aston Business School.

Winder, R. (1999, May 16). A grand departure goes uncelebrated. The Independent on Sunday, p. 8.

Wood, M. (2002). Mind the gap? A processual reconsideration of organisational knowledge. Organization, 9(1), 151-171.

Young, T. (1999). How to be a better project manager. London: Kogan Page.

Young, T. (2003). The handbook of project management - A practical guide of effective policies and procedures. London: Kogan Page.
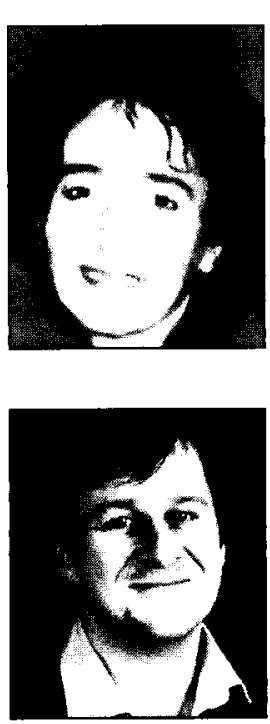

SVETLANA CICMIL, BSC (Civ. Eng), MBA, PhD, is the head of research in operations and information management and director of MBA Programmes at Bristol Business School, University of the West of England, U.K. She has an extensive international teaching, consultancy and industrial experience in the field of project management. Svetlana's specific research interests lie in the areas of complexity theory and sociology of project based work, project management education, and the development of project management skills, competencies, and knowledge. She is also interested in the global aspects of management education, and the international transfer of management knowledge. Svetlana is actively involved in Project Management Research Networks, regularly speaks at conferences and has published widely. Recent articles written by Svetlana have appeared in International Journal of Project Management, Building Research and Information, and International Journal of Diversity in Organisations, Communities, and Nations. In collaboration with Dr. Hodgson, Svetlana published an influential book Making Projects Critical (Palgrave), drawing on a series of distinctive workshops with the same name with contributions from a range of international researchers.

DAMIAN HODGSON BA (HONS), MA, PhD is senior lecturer in organisational analysis at Manchester Business School, University of Manchester. His key research theme at present is the phenomenon of projects in work organisations, encompassing an analysis of the emergence of project-based organisations, the widespread adoption of project working across a range of industries, and ongoing efforts to institutionalise project management as a professional discipline. In particular, he is keen to promote a critical analysis of project management knowledge, in terms of its epistemology, ontology and related core assumptions. Damian is also co-investigator on the EPSRC-funded network entitled "Rethinking Project Management" (www.rethinkingpm.org.uk. He has presented work at a variety of international conferences including the Academy of Management, the Critical Management Studies Conference, the British Academy of Management, and EGOS, and has published in a range of journals including the Journal of Management Studies, Organization, Management Decision and Gender, Work and Organisation. 
Copyright of Project Management Journal is the property of Project Management Institute and its content may not be copied or emailed to multiple sites or posted to a listserv without the copyright holder's express written permission. However, users may print, download, or email articles for individual use. 